\title{
KAPASITAS PERIKANAN PELAGIS KECIL DI WILAYAH PENGELOLAAN PERIKANAN-714 LAUT BANDA MALUKU
}

\author{
Johanis Hiariey ${ }^{1)}$ dan Mulyono Sumitro Baskoro ${ }^{2)}$ \\ 1) Dosen pada Fakultas Perikanan dan Ilmu Kelautan-Universitas Pattimura, Ambon \\ 2) Dosen pada Fakultas Perikanan dan Ilmu Kelautan-Institut Pertanian Bogor, Bogor \\ Teregistrasi I tanggal: 9 April 2010; Diterima setelah perbaikan tanggal: 20 April 2010; \\ Disetujui terbit tanggal: 30 April 2010
}

\begin{abstract}
ABSTRAK
Kapasitas penangkapan berlebih merupakan suatu masalah kritis pada perikanan tangkap. Berkaitan dengan isu kapasitas tersebut, kajian ini dilakukan untuk menentukan kapasitas penangkapan ikan pelagis kecil di wilayah pengelolaan perikanan-714 Laut Banda, dengan menggunakan data runtun waktu periode tahun 1985-2006 yang dianalisis dengan teknik data envelopment analysis. Terdapat indikasi excess capacity pada perikanan pelagis kecil, dan pada periode tahun 1989-1998 kondisi perikanan menunjukan over capacity. Dengan demikian, dibutuhkan alternatif kebijakan pengelolaan perikanan untuk mengurangi input penangkapan pada perikanan di wilayah pengelolaan perikanan-714 Laut Banda.
\end{abstract}

KATAKUNCI: perikanan pelagis kecil, kapasitas penangkapan, data envelopment analysis, Laut Banda

ABSTRACT: $\quad$ Pelagis small fishing capacity management of fisheries in Banda Sea-714 Maluku. By: Johanis Hiariey and Mulyono Sumitro Baskoro

Excessive fishing capacity is a critical problem in marine capture fisheries. In line with the capacity issue, this study was conducted to determine fishing capacity of the small pelagic fishery at fishery management area-714 Banda Sea using time series data of 1985-2006 analyzed using technique of data envelopment analysis. There was indication of excess capacity on the small pelagic fishery, and the fishery in the period of 1989-1998 was found to be over capacity. Therefore, alternative fishery management policies were needed to reduce fishing inputs from the fishery of the fishery management area-714 Banda Sea.

KEYWORDS: $\quad$ small pelagic fishery, fishing capacity, data envelopment analysis, Banda Sea

\section{PENDAHULUAN}

Wilayah pengelolaan perikanan Laut Banda (Nurhakim et al., 2007) merupakan kawasan penting di Maluku mengandung sumber daya ikan pelagis kecil yang cukup potensial (Departemen Kelautan dan Perikanan, 2006). Potensi tersebut dieksploitasi oleh nelayan yang berbasis di Maluku Tengah dan sekitarnya dengan menggunakan pukat cincin, jaring insang, bagan, dan pukat pantai.

Eksploitasi pelagis kecil di wilayah pengelolaan perikanan-741 Laut Banda mulai berkembang pesat sejak awal tahun 
1980-an. Tingkat pemanfaatannya pada tahun 2005 telah mencapai 146.470 ton (Departemen Kelautan dan Perikanan, 2006), sedangkan potensinya diestimasi sekitar 132.000 ton per tahun (Badan Riset Kelautan dan Perikanan \& Lembaga IImu Pengetahuan Indonesia, 2001). Hasil observasi penangkapan ikan pelagis kecil di Maluku Tengah dan Kota Ambon mengindikasikan penurunan produksi ratarata (catch per unit of effort) alat tangkap pukat cincin dan bagan. Oleh sebab itu, jika tidak dikendalikan maka keberlangsungan eksploitasi akan terganggu dan menimbulkan penurunan produktivitas nelayan di pesisir wilayah pengelolaan perikanan-714 Laut Banda.

Pengendalian eksploitasi dapat dilakukan dengan pendekatan berbasis kapasitas sebagai dasar pertimbangan kebijakan. Kapasitas perikanan merupakan stok kapital maksimum dalam perikanan yang dapat digunakan secara penuh pada kondisi efisiensi maksimum secara teknis pada waktu dan kondisi pasar tertentu (Fauzi \& Anna, 2005). Kapasitas tersebut bersifat krusial dan global, dan telah mendapat perhatian Food and Agriculture Organization sejak tahun 1999. Perhatian Food and Agriculture Organization diwujudkan melalui seruannya agar perikanan di dunia termasuk Indonesia dikelola dalam kapasitas perikanan yang efisien, equitable, dan transparan (Fauzi, 2005).

Dimensi kapasitas perikanan merupakan faktor penting dalam menyediakan informasi strategis bagi arahan implementasi kebijakan, ketika timbul gejala penurunan produksi perikanan tangkap. Salah satu teknik pengukuran kapasitas yang digunakan Food and Agriculture Organization adalah data envelopment analysis. Pendekatan data envelopment analysis merupakan teknik pengukuran kinerja untuk mengevaluasi efisiensi relatif dari unit pengambil keputusan (decision making unit) dalam kegiatan pada periode waktu tertentu. Pendekatan dimaksud berorientasi output dan input, dikembangkan oleh Charnes, Cooper, and Rhodes dan dilanjutkan oleh Fare et al. (1989; 1994), yang diacu dalam Fauzi \& Anna (2005). Aplikasi data envelopment analysis pada perikanan dikatakan oleh Kirkley \& Squires (1998). Hasil evaluasi data envelopment analysis dapat menjelaskan apakah kegiatan perikanan di suatu wilayah perairan laut telah efisien dari sisi economic over fishing, jika terdapat indikasi penurunan produksi akibat input yang dikorbankan telah melebihi sumber daya ikan yang dieksploitasi.

Teknik data envelopment analysis didasarkan atas pendekatan program matematis yang dapat menentukan solusi optimal berkaitan dengan kendala-kendala yang ada (Charnes et al., 1994; Fare et al., 1989, yang diacu dalam Kirkley et al., 2004). Hasil pengukuran efisiensi dengan data envelopment analysis bersifat bebas nilai karena didasarkan atas data yang tersedia tanpa mempertimbangkan penilaian dari pengambil keputusan (Korhonen et al., 1998, yang diacu dalam Fauzi \& Anna, 2005). Di samping itu, perbedaan-perbedaan satuan pengukuran dari input dan output pada perikanan tangkap juga dapat dianalisis dengan data envelopment analysis (van Hoof \& de Wide, 2005). Hasil analisis data envelopment analysis perikanan tangkap berupa efisiensi teknologi relatif terhadap teknologi frontier optimal, dalam kondisi best practice yang diamati dalam suatu kegiatan armada penangkapan. Teknologi frontier pada output orientation berupa kombinasi input (tonase kapal dan tenaga mesin) optimal dan output (hasil tangkapan). 
Keunggulan teknik data envelopment analysis adalah dapat mengestimasi kapasitas perikanan di bawah kendalakendala penerapan kebijakan seperti jumlah tangkapan yang diperbolehkan (TAC), ukuran kapal, pajak, dan kendala sosial-ekonomi (Kirkley \& Squires, 1998); dapat mengakomodir multiple outputs dan multiple inputs, dengan sifat nondiskret, serta penentuan tingkat potensial maksimum dari variabel input dan laju optimalnya; dan memungkinkan adanya penentuan kombinasi input variabel, output variabel, input tetap, dan karakteristik perusahaan perikanan dalam memaksimalkan output dan meminimalkan input. Oleh karena itu, hasil data envelopment analysis bermanfaat untuk menganalisis kapasitas perikanan atau menilai efisiensi kebijakan perikanan.

Penelitian perikanan dengan teknik data envelopment analysis telah berkembang dalam dua dekade terakhir. Vestergaard et al. (2003), telah menerapkan teknik data envelopment analysis dalam mengkaji kapasitas perikanan multi species di Danish untuk mengukur pemanfaatan kapasitas. Begitupun penerapan data envelopment analysis untuk mengukur kapasitas perikanan pukat cincin di Pekalongan untuk mengetahui kondisi over capacity atau inefisiensi dalam pengurangan upaya penangkapan (Efendi, 2007). Desniarti (2007), telah mengaplikasikan data envelopment analysis untuk mengukur kapasitas perikanan tangkap pelagis kecil di perairan Sumatera Barat. Hasilnya menunjukan efisiensi perikanan tangkap yang menurun dan pemanfaatan pelagis kecil mengarah over fishing dan over capacity dalam periode penelitian. Hiariey (2009) telah menerapkan teknik data envelopment analysis dalam kajian untuk menentukan status eksploitasi sumber daya ikan pelagis kecil di perairan Maluku.
Kirkley \& Squires (1998) mengatakan kapasitas dapat diukur berdasarkan atas ketersediaan ataupun tidak berdasarkan atas ketersediaan stok sumber daya. Pada pengukuran berdasarkan atas ketersediaan stok, kapasitas perikanan merupakan potensi maksimum output dihasilkan melalui tingkat sumber daya yang tersedia. Sebaliknya pengukuran tanpa ketersediaan stok dapat dipandang sebagai output potensil yang dihasilkan tanpa kendala sumber daya. Kapasitas perikanan dalam penelitian ini didasarkan atas konsep pengukuran tanpa kendala sumber daya, sehingga tingkat ketersediaan stok tidak dikategorikan sebagai input. Kajian ini bertujuan untuk mengkaji perubahan kapasitas perikanan pelagis kecil menurut waktu di wilayah pengelolaan perikanan-714 Laut Banda.

Kapasitas perikanan pelagis kecil diestimasi berdasarkan atas data runtun waktu tahun 1985-2006 di mana upaya dan alat tangkap sebagai variabel input dan produksi ikan sebagai variabel output. Kajian ini memperlakukan periode tahunan sebagai decision making unit, sehingga perkembangan kinerja kapasitas dievaluasi dengan basis decision making unit.

Diasumsikan tranformasi input dan output pada fungsi produksi perikanan bersifat variable return to scale, maka model data envelopment analysis dimodifikasi sesuai model yang dikembangkan oleh Banker, Charnes, and Cooper (Fauzi \& Anna, 2005). Spesifikasi tersebut memungkinkan dilakukan analisis efisiensi aktivitas ekonomi yang bersifat variable return to scale. Tipe data envelopment analysis minimisasi input dengan asumsi model bersifat variable return to scale sebagai alat analisis diformulasikan sebagai: 
tersebut sangat dipengaruhi oleh jumlah alat tangkap yang dimiliki. Investasi yang diperlukan dalam kegiatan usaha yang dikeluarkan nelayan berkisar antara Rp.500.000-Rp.1.400.000,-.

Kelayakan usaha penangkapan menunjukan bahwa pada beberapa jenis alat tangkap, usaha penangkapan ikan cukup menguntungkan dan layak untuk diusahakan, dengan tingkat kelayakan usaha bervariasi antara 2,3-21,6 (Tabel 8).

Saat ini jumlah pembudidaya ikan dalam keramba 379 RTP yang terdiri atas pembudidaya ikan keramba (29 RTP), dan pembudidaya ikan jaring apung (350 RTP).
Pada perikanan budi daya, hampir seluruh ikan hasil budi daya dijual di lokasi budi daya. Pembeli mendatangi lokasi budi daya secara periodik dan membeli hasil budi daya secara bertahap. Tingkat harga jual di lokasi untuk jenis ikan nila dapat mencapai Rp.12.000/kg, dengan tingkat harga tersebut maka pembudidaya dapat memperoleh keuntungan usaha rata-rata Rp.14.278 juta/petak/ musim. Dari hasil perhitungan di atas, dapat diketahui bahwa nilai B/C mencapai 2,1 artinya bahwa untuk setiap rupiah yang dikeluarkan akan memberikan kontribusi keuntungan Rp.2,1. Kegiatan budi daya sistem keramba tancap di Danau Limboto cukup menguntungkan dan layak untuk diusahakan.

Tabel 8. Kelayakan usaha pada beberapa jenis alat tangkap di Danau Limboto Table 8. Feasibility study on several types of fishing gear in Lake Limboto

\begin{tabular}{|c|c|c|c|c|c|c|}
\hline $\begin{array}{c}\text { Jenis alat } \\
\text { tangkapl } \\
\text { Types of } \\
\text { fishing } \\
\text { gear }\end{array}$ & $\begin{array}{l}\text { Kepemilikan } \\
\text { alat tangkap/ } \\
\text { Ownership } \\
\text { fishing } \\
\text { gear } \\
\text { (unit/RTP) }\end{array}$ & $\begin{array}{c}\text { Hasil } \\
\text { tangkapan/ } \\
\text { Haul } \\
\text { (kg/trip)/ } \\
\text { (kg/musim) }\end{array}$ & $\begin{array}{l}\text { Jenis ikan } \\
\text { tangkapan/ } \\
\text { Type of fish } \\
\text { catches }\end{array}$ & Rp/hari & $\begin{array}{l}\text { atan/Income } \\
\text { Rp/bulan*) } \\
\text { dan atau } \\
\text { (Rp/musim) }\end{array}$ & $\begin{array}{c}\text { Kelayakan } \\
\text { usahal } \\
\text { Feasibility } \\
\text { study } \\
\text { (R/C ratio) }\end{array}$ \\
\hline $\begin{array}{l}\text { Pajala } \\
\text { /Gillnet }\end{array}$ & 3 & 4,8 & $\begin{array}{l}\text { Mujair, nila, } \\
\text { manggabai, } \\
\text { tawes, sepat, } \\
\text { payangga, } \\
\text { gabus }\end{array}$ & 25.376 & 761.265 & 3,9 \\
\hline Dudayaho & 1 & 30,0 & Hulu'u & 25.509 & 765.292 & 2,4 \\
\hline $\begin{array}{l}\text { Jaring } \\
\text { tancap }\end{array}$ & 1 & 6,0 & $\begin{array}{l}\text { Nila, } \\
\text { manggabai }\end{array}$ & 35.175 & 1.055 .250 & 3,0 \\
\hline Bunggo & 200 & 7,0 & $\begin{array}{l}\text { Sogili, } \\
\text { mangagbai, } \\
\text { payangka }\end{array}$ & 186.356 & 5.590 .679 & 21,6 \\
\hline $\begin{array}{l}\text { Bibilo } \\
\left(200 \mathrm{~m}^{2}\right)\end{array}$ & 3 & 600 & $\begin{array}{l}\text { Nila, mujair, } \\
\text { gabus, } \\
\text { tawes }\end{array}$ & 42.476 & 7.645 .689 & 11,3 \\
\hline
\end{tabular}

\section{PENGELOLAAN PERIKANAN}

Berdasarkan atas uraian sebelumnya maka langkah-langkah pengelolaan perikanan yang perlu dilakukan meliputi:
1. Rehabilitasi habitat danau

Rehabilitasi habitat danau perlu dilakukan terutama dengan cara mengendalikan gulma air eceng gondok. 
$\mathrm{TE}=\operatorname{Min} \theta$

dengan kendala,

$$
\theta u_{j} \leq \sum_{j=1}^{J} z_{j} u_{j}
$$

$\sum_{j=1}^{J} z_{j} x_{j n} \leq x_{j n}, \quad n \in a$

$$
\begin{array}{r}
\sum_{j=1}^{J} z_{j} x_{j n}=\lambda_{j} x_{j n}, \quad n \in \hat{a} \ldots \ldots \ldots \ldots \ldots .(5 \\
\lambda_{j n} \geq, j=1,2, \ldots, J, n=1,2, \ldots, N .(6
\end{array}
$$

di mana:

$$
\begin{aligned}
\mathrm{j}= & 1,2, \ldots, \\
\mathrm{J}= & \text { total tahun observasi, sehingga } \\
& \text { terdapat } 22 \text { tahun pengamatan atau } \\
& 22 \text { decision making unit }
\end{aligned}
$$

Oleh karena input terdiri atas alat tangkap dan trip penangkapan, maka $n=1$, $2, \ldots . ., \mathrm{N}$

di mana,

$\mathrm{TE}=$ nilai efisiensi teknis tahun ke-j (Nilai: 0-1)

$\theta=$ nilai pengukuran setiap pengamatan, $>1$, (unit ukur input dan/atau output per tahun)

$\mathrm{u}_{\mathrm{j}}=$ output untuk tahun ke-j, yaitu satu output atau hasil tangkapan (ton)

$\mathrm{x}_{\mathrm{in}}=$ input ke-n yang digunakan, terdiri atas dua jenis input (jumlah upaya penangkapan, dalam trip) dan (jumlah alat tangkap, dalam unit)

$\ddot{e}_{j} \quad=$ tingkat penggunaan input variabel ke-n $\mathrm{z}_{\mathrm{j}} \quad=$ intensitas penggunaan variabel

Model data envelopment analysis spesifikasi variable return to scale dimanfaatkan untuk mengetahui berapa output yang dihasilkan oleh sejumlah upaya penangkapan tanpa pengurangannya, dan berapa jumlah alat tangkap yang dikurangi tanpa perubahan jumlah output. Dengan demikian analisis efisiensi teknis skala variable return to scale berorientasi input digunakan untuk mengetahui tingkat penggunaan input untuk menghasilkan output, dan sekaligus menggambarkan perubahan skala efisiensi teknis untuk setiap decision making unit. Penggunaan skala variable return to scale dalam analisis efisiensi didasarkan atas dugaan bahwa unit penangkapan ikan pelagis kecil yang beroperasi di perairan wilayah pengelolaan perikanan-714 Laut Banda menemui kendala pembiayaan (Coelli, 1996); dan tidak semua unit penangkapan beroperasi pada skala optimum. Dengan demikian, dederatan Banker, Charnes, and Cooper steplja $=$ variable return to scale yang berorientasi input digunakan untuk menganalisis efisiensi teknis.

Cooper et al. (2000) yang dikutip dalam Lindebo (2004) mengatakan derajad bebas analisis data envelopment analysis akan meningkat dengan bertambah decision making unit, sebaliknya akan berkurang dengan bertambahnya jenis input dan output. Dengan demikian, rule of thumb untuk tingkat kepercayaan pada jumlah pengamatan minimal adalah:

$$
\mathrm{n} \geq \max \left\{\mathrm{m}^{*} \mathrm{~s}, 3(\mathrm{~m}+\mathrm{s})\right\}
$$

di mana:

$\mathrm{n}=$ jumlah pengamatan minimal

$\mathrm{m}=$ jumlah jenis input

$\mathrm{s}=$ jumlah output 


\section{HASIL DAN BAHASAN}

Perikanan pelagis kecil di perairan Laut Banda menggunakan pukat cincin, jaring insang, bagan, dan pukat pantai sebagai alat tangkap utama dan dominan di perairan tersebut. Pukat cincin oleh nelayan lokal disebut jaring bobo merupakan alat tangkap yang produktif di perairan pesisir Laut Banda. Musim penangkapan pelagis kecil yang efektif adalah bulan Maret sampai Oktober atau musim timur (Merta et al., 1998), berkaitan dengan proses upwelling yang berlangsung pada musim tersebut. Perkembangan perikanan pelagis kecil dimulai sejak pertengahan tahun 1970 -an, dengan diperkenalkannya alat pukat cincin berukuran lebih kecil dari $30 \mathrm{GT}$, menggunakan mesin ketinting sebagai tenaga penggerak. Kemudian, pertengahan tahun 1980-an nelayan lokal terus mengembangkan alat tangkap pukat cincin berukuran panjang $250 \mathrm{~m}$ dan lebar $75 \mathrm{~m}$ dengan kapal berukuran panjang $22 \mathrm{~m}$, lebar $3 \mathrm{~m}$, dan tinggi 1,5 m, menggunakan mesin penggerak jenis Yamaha $40 \mathrm{PK}$.

Rata-rata produksi ikan pelagis kecil per decision making unit di lokasi penelitian $27.145,87$ ton dengan upaya penangkapan rata-rata 582.214 trip, serta alat tangkap yang digunakan rata-rata 6.005 unit/tahun (Tabel 1).

Tabel 1. Deskripsi statistik perikanan pelagis kecil per decision making unit Table 1. Statistic descriptions of the small pelagic fishery in each decision making unit

\begin{tabular}{lccccc}
\hline $\begin{array}{l}\text { Variabell } \\
\text { Variable }\end{array}$ & $\mathbf{N}$ & $\begin{array}{c}\text { Rata-ratal } \\
\text { Average }\end{array}$ & $\begin{array}{c}\text { St deviasil } \\
\text { Standard of deviation }\end{array}$ & $\begin{array}{c}\text { Minimuml } \\
\text { Minimum }\end{array}$ & $\begin{array}{c}\text { Maksimum/ } \\
\text { Maximum }\end{array}$ \\
\hline Produksi & 22 & $27.145,87$ & $10.636,5947$ & $14.225,72$ & $62.314,70$ \\
Upaya & 22 & 582.214 & $191.293,0643$ & 176.901 & 771.741 \\
Alat tangkap & 22 & 6.005 & $2.703,17$ & 3.051 & 11.658 \\
\hline
\end{tabular}

Perkembangan produksi pelagis kecil pada Gambar 1 berfluktuasi dan cenderung meningkat sejak tahun 2001-2006. Produksi terendah tercatat pada tahun 1985 dan tertinggi dicapai tahun 2006. Perubahan alokasi faktual upaya penangkapan (Gambar 2) bervariasi dan relatif meningkat sejak tahun 1985-1998, kemudian cenderung menurun sejak tahun 1999-2006. Berbeda dengan upaya faktual, alokasi armada penangkapan relatif meningkat sejak tahun 1985-1998, dan meningkat tajam sejak tahun 1999-2006 (Gambar 3). Kecenderungan penurunan upaya penangkapan pada periode tahun 19992006 berkaitan dengan pengurangan upaya sebagai dampak konflik sosial Maluku tahun 1999.
Hasil analisis data envelopment analysis skala variable return to scale memberikan skala efisiensi penggunaan input yang bersifat increasing, constant dan decreasing return to scale. Ini mengindikasikan perubahan skala efisiensi perikanan berfluktuasi dan sebagian besar bersifat increasing rate to scale. Sifat increasing rate to scale menggambarkan nilai proporsi tingkat penggunaan input adalah lebih rendah dibandingkan proporsi tingkat pertambahan output. Fluktuasi efisiensi penggunaan input diakibatkan oleh kecenderungan penurunan upaya penangkapan selama periode tahun 19852006, namun unit alat penangkap ikan dan produksi cenderung meningkat. 


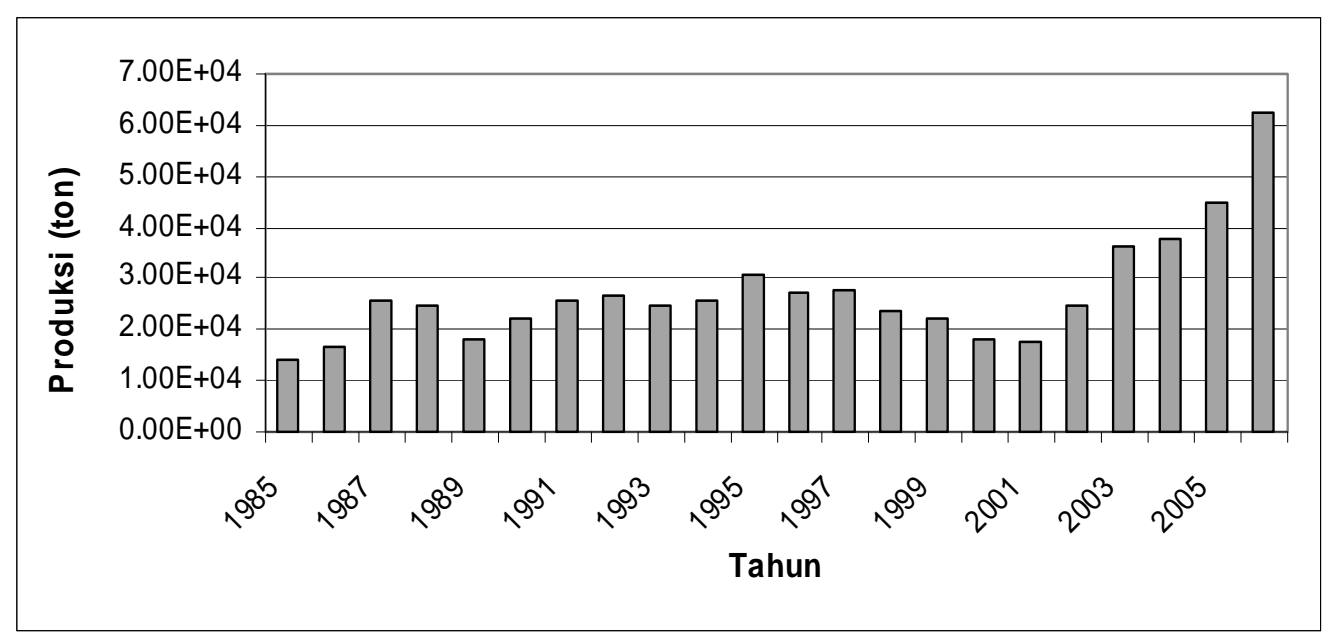

Gambar 1. Produksi ikan pelagis kecil tahun 1985-2006.

Figure 1. Small pelagic fish production of 1985-2006.

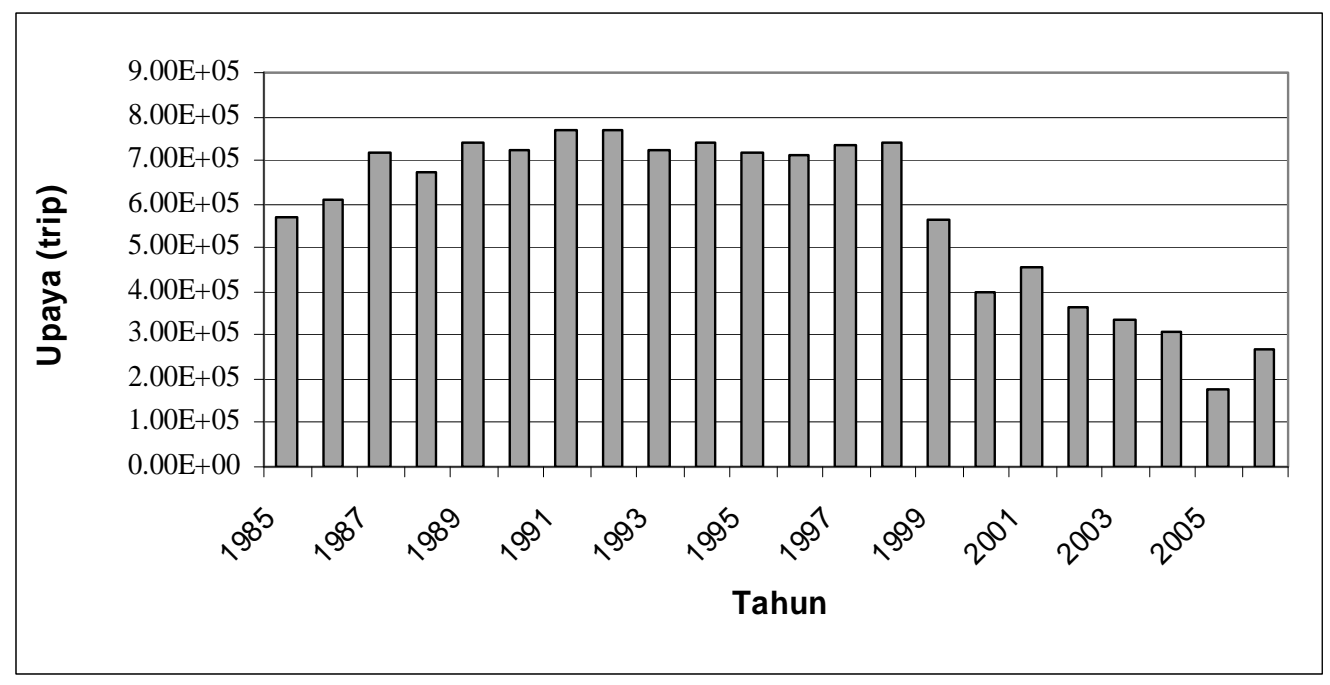

Gambar 2. Alokasi upaya penangkapan pelagis kecil tahun 1985-2006

Figure 2. Trip allocation on the small-pelagic fishing of 1985-2006 


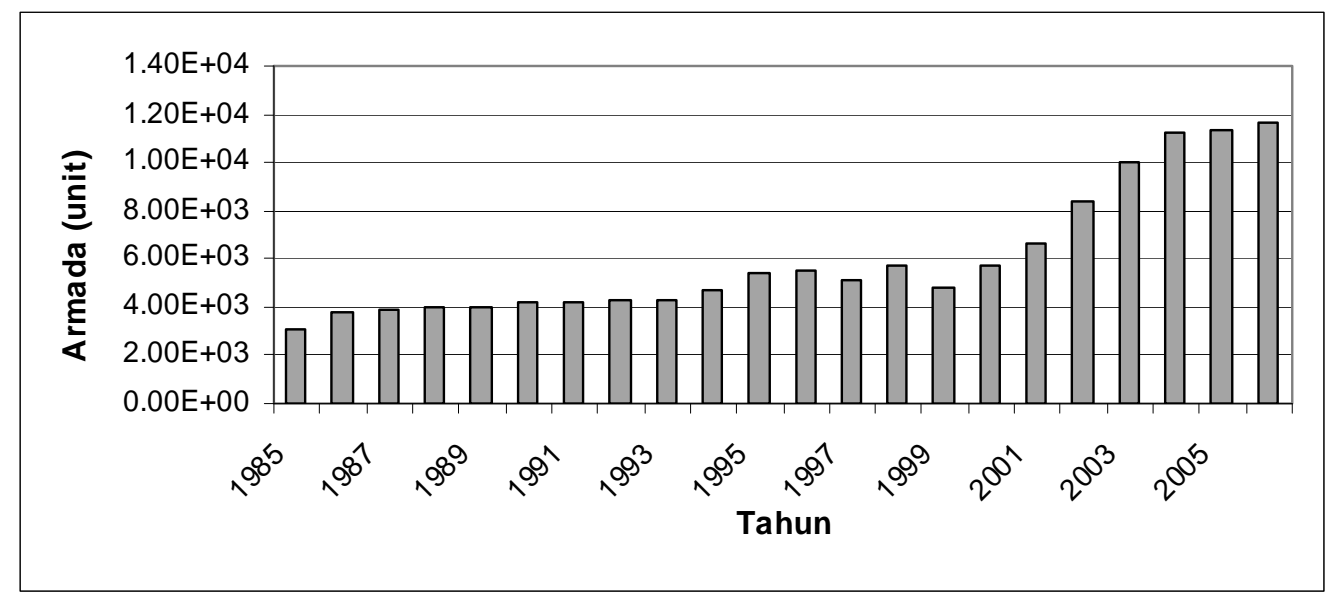

Gambar 3. Perkembangan armada penangkapan tahun 1985-2006

Figure 3. Fishing fleet development of 1985-2006

Hasil data envelopment analysis memberikan dimensi efisiensi relatif perikanan pelagis kecil di wilayah pengelolaan perikanan-714 Laut Banda (Tabel 2). Terdapat enam decision making unit dengan efisiensi bernilai satu, dan digunakan sebagai pembanding untuk menentukan efisiensi relatif. Nilai efisiensi sama dengan satu, yang berskala constant ditemui pada decision making unit-tahun 1987, decision making unit-tahun 2005, dan decision making unit-tahun 2006. Dengan demikian, ketiga decision making unit tersebut tergolong sangat efisien. Skor efisiensi penggunaan input selama periode tahun 1985-2006 berkisar antara 0,763-1. Kisaran tersebut menunjukan efisiensi masing-masing alat tangkap adalah lebih besar 70\%. Fare et al. (2000), mengatakan bahwa jika efisiensi input lebih kecil dari satu, berarti input yang digunakan tidak efisien dan dapat dikurangi satu dikurangi nilai efisiensi input.

Nilai efisiensi perikanan pelagis kecil di perairan wilayah pengelolaan perikanan-714 Laut Banda relatif berfluktuasi sejak tahun 1985-2006. Penurunan efisiensi menjadi 83,8\% terjadi tahun 1989 jika dibandingkan tahun 1987. Kecenderungan peningkatan efisiensi terlihat pada tahun 1989-1992 karena proporsi peningkatan produksi lebih besar dibanding proporsi peningkatan unit penangkapan ikan, sedangkan fluktuasi trip penangkapan relatif kecil. Nilai efisiensi relatif tahun 2001-2004 adalah lebih rendah jika dibandingkan tahun 2005 dan 2006. Rendahnya tingkat efisiensi pada periode tersebut karena peningkatan produksi pelagis kecil juga diikuti dengan peningkatan jumlah unit penangkapan ikan pelagis kecil, walaupun trip menurun. 
Tabel 2. Efisiensi perikanan pelagis kecil di wilayah pengelolaan perikanan-714 Laut Banda

Table 2. Efficiency of small pelagic fishery at fishery management area-714 Banda Sea

\begin{tabular}{cccl}
\hline $\begin{array}{c}\text { Nomorl } \\
\text { Number }\end{array}$ & $\begin{array}{c}\text { DMU (tahun)I } \\
\text { DMU (year) }\end{array}$ & $\begin{array}{c}\text { Skor BCC (VRS)I } \\
\text { BCC score (VRS) }\end{array}$ & $\begin{array}{l}\text { Skalal } \\
\text { Scale }\end{array}$ \\
\hline 1. & 1985 & 1,000 & Increasing \\
2. & 1986 & 0,909 & Increasing \\
3. & 1987 & 1,000 & Constant \\
4. & 1988 & 1,000 & Increasing \\
5. & 1989 & 0,838 & Increasing \\
6. & 1990 & 0,897 & Increasing \\
7. & 1991 & 0,931 & Increasing \\
8. & 1992 & 0,951 & Decreasing \\
9. & 1993 & 0,915 & Increasing \\
10. & 1994 & 0,882 & Increasing \\
11. & 1995 & 0,925 & Decreasing \\
12. & 1996 & 0,849 & Increasing \\
13. & 1997 & 0,881 & Increasing \\
14. & 1998 & 0,763 & Increasing \\
15. & 1999 & 0,931 & Increasing \\
16. & 2000 & 1,000 & Increasing \\
17. & 2001 & 0,869 & Increasing \\
18. & 2002 & 0,903 & Increasing \\
19. & 2003 & 0,890 & Increasing \\
20. & 2004 & 0,849 & Increasing \\
21. & 2005 & 1,000 & Constant \\
22. & 2006 & 1,000 & Constant \\
\hline
\end{tabular}

Skor efisiensi terendah pada tahun 1998 , sebesar $76,3 \%$ disebabkan peningkatan upaya penangkapan $0,3 \%$, tetapi produksi menurun $16 \%$ dibanding tahun sebelumnya. Rendahnya nilai efisiensi disebabkan terjadi peningkatan unit penangkapan ikan $11,9 \%$, namun produksi menurun $16 \%$. Diasumsikan decreasing return to scale terjadi pada kondisi efisiensi terendah, maka pengelolaan perikanan pelagis kecil di perairan wilayah pengelolaan perikanan714 Laut Banda terindikasi over capacity atau kapasitas berlebih. Indikasi over capacity tersebut juga diperlihatkan oleh skor efisiensi pada sebagian besar decision making unit yang lebih kecil dari satu $(\mathrm{TE}<1)$.

Hasil analisis data envelopment analysis menunjukan potensi peningkatan input decision making unit yang bersifat negatif. Sifat tersebut memberikan indikasi over capacity pada perikanan pelagis kecil, yang menimbulkan ketidak-efisienan dalam jangka panjang.

Penggunaan input optimal pada skala efisiensi constant ditemui pada decision making unit-tahun 1987, decision making unit-tahun 2005, dan decision making unit2006. Pada kondisi tersebut, seluruh input dimanfaatkan penuh atau tidak terdapat potensi peningkatan input. Dengan demikian pengelolaan perikanan pelagis kecil bersifat efisien. Pada decision making unit-tahun 1995, terjadi inefisiensi perikanan pelagis kecil 0,925 dengan skala decreasing return to scale. Untuk menghasilkan penggunaan input secara optimal maka upaya penangkapan 
dikurangi $9,13 \%$, dan unit penangkapan $7,45 \%$. Pada tahun 2001, terjadi inefisiensi perikanan pelagis kecil 0,869. Untuk mencapai efisiensi penggunaan input maka upaya penangkapan dan alat tangkap masing-masing dikurangi $13,08 \%$, dan pengurangan input diharapkan dapat meningkatkan produksi $5,79 \%$.

Tabel 3 memperlihatkan indikasi excess capacity (selisih antara kapasitas input target dengan input aktual) yang bernilai negatif pada sebagian besar decision making unit, kecuali decision making unittahun 1985, decision making unit-tahun 1987, decision making unit-tahun 1988, decision making unit-tahun 2000 , decision making unit-tahun 2005, dan decision making unit-2006 (penggunaan kedua input adalah optimal atau fully utilized). Hasil analisis juga menunjukan bahwa excess capacity yang tertinggi terjadi pada decision making unit-tahun 1998 (23,71\%), kemudian diikuti oleh decision making unittahun 1989 (16,21\%), decision making unittahun $1996(15,21 \%)$, dan decision making unit-tahun 2004 (15,04\%). Excess capacity tersebut mengindikasikan pengalokasian input (upaya dan unit alat penangkap ikan) relatif tinggi dalam penangkapan ikan pelagis kecil di perairan wilayah pengelolaan perikanan-714 Laut Banda. Kirkley et al. (2004) mengatakan bahwa, nilai efisiensi DMU $<1$, dapat digolongkan sebagai excess capacity dan apabila excess capacity berlangsung dalam jangka panjang akan menimbulkan over capacity.

Tabel 3. Kapasitas berlebih perikanan pelagis kecil di wilayah pengelolaan perikanan714 Laut Banda, tahun 1985-2006

Table 3. Excess capacity of the small pelagic fishery at fishery management area-714 Banda Sea of 1985-2006

\begin{tabular}{|c|c|c|c|c|c|c|c|c|}
\hline \multirow{3}{*}{$\begin{array}{c}\text { DMU (Tahun)/ } \\
\text { DMU (year) }\end{array}$} & \multicolumn{2}{|c|}{$\begin{array}{l}\text { Input aktuall } \\
\text { Actual input }\end{array}$} & \multicolumn{2}{|c|}{$\begin{array}{l}\text { Kapasitas input (target) } \\
\text { IInput capacity (target) }\end{array}$} & \multicolumn{4}{|c|}{$\begin{array}{l}\text { Kapasitas berlebih/ } \\
\text { Excess capacity }\end{array}$} \\
\hline & \multirow{2}{*}{$\begin{array}{c}\text { Upayal } \\
\text { Effort } \\
\text { (trip) }\end{array}$} & \multirow{2}{*}{$\begin{array}{c}\text { Unit APII } \\
\text { Fishing unit } \\
\text { (unit) }\end{array}$} & \multirow{2}{*}{$\begin{array}{l}\text { Upayal } \\
\text { Effort } \\
\text { (trip) }\end{array}$} & \multirow{2}{*}{$\begin{array}{c}\text { Unit APII } \\
\text { Fishing unit } \\
\text { (unit) }\end{array}$} & \multicolumn{2}{|c|}{$\begin{array}{l}\text { Upayal } \\
\text { Effort }\end{array}$} & \multicolumn{2}{|c|}{$\begin{array}{c}\text { Unit APII } \\
\text { Fishing unit }\end{array}$} \\
\hline & & & & & (trip) & $\%$ & (unit) & $\%$ \\
\hline 1985 & 571.554 & 3.051 & 571.554 & 3.051 & 0 & 0,00 & 0 & 0,00 \\
\hline 1986 & 611.709 & 3.831 & 555.909 & 3.482 & -55.800 & $-9,12$ & -349 & $-9,12$ \\
\hline 1987 & 716.172 & 3.898 & 716.172 & 3.898 & 0 & 0,00 & 0 & 0,00 \\
\hline 1988 & 671.393 & 3.935 & 671.393 & 3.935 & 0 & 0,00 & 0 & 0,00 \\
\hline 1989 & 741.059 & 4.014 & 620.935 & 3.363 & -120.124 & $-16,21$ & -651 & $-16,21$ \\
\hline 1990 & 722.333 & 4.158 & 647.865 & 3.729 & -74.468 & $-10,31$ & -429 & $-10,31$ \\
\hline 1991 & 771.741 & 4.182 & 715.240 & 3.893 & -56.501 & $-7,32$ & -289 & $-6,92$ \\
\hline 1992 & 768.626 & 4.299 & 705.114 & 4.090 & -63.512 & $-8,26$ & -209 & $-4,85$ \\
\hline 1993 & 722.712 & 4.338 & 661.204 & 3.969 & -61.508 & $-8,51$ & -369 & $-8,51$ \\
\hline 1994 & 738.624 & 4.741 & 651.232 & 4.180 & -87.392 & $-11,83$ & -561 & $-11,83$ \\
\hline 1995 & 720.247 & 5.371 & 654.486 & 4.971 & -65.761 & $-9,13$ & -400 & $-7,45$ \\
\hline 1996 & 712.503 & 5.488 & 605.217 & 4.662 & -107.286 & $-15,06$ & -826 & $-15,06$ \\
\hline 1997 & 735.705 & 5.159 & 647.836 & 4.543 & -87.869 & $-11,94$ & -616 & $-11,94$ \\
\hline 1998 & 738.011 & 5.773 & 563.007 & 4.404 & -175.004 & $-23,71$ & -1.369 & $-23,71$ \\
\hline 1999 & 561.427 & 4.809 & 522.461 & 4.475 & -38.966 & $-6,94$ & -334 & $-6,94$ \\
\hline 2000 & 399.399 & 5.734 & 399.399 & 5.734 & 0 & 0,00 & 0 & 0,00 \\
\hline 2001 & 457.296 & 6.654 & 397.460 & 5.783 & -59.836 & $-13,08$ & -871 & $-13,08$ \\
\hline 2002 & 361.767 & 8.393 & 326.780 & 7.581 & -34.987 & $-9,67$ & -812 & $-9,67$ \\
\hline 2003 & 333.791 & 9.994 & 297.106 & 8.896 & -36.685 & $-10,99$ & -1.098 & $-10,99$ \\
\hline 2004 & 305.815 & 11.231 & 259.788 & 9.541 & -46.027 & $-15,05$ & -1.690 & $-15,05$ \\
\hline 2005 & 176.901 & 11.394 & 176.901 & 11.394 & 0 & 0,00 & 0 & 0,00 \\
\hline 2006 & 269.917 & 11.658 & 269.917 & 11.658 & 0 & 0,00 & 0 & 0,00 \\
\hline
\end{tabular}


Indikasi kapasitas berlebih (excess capacity) pada perikanan pelagis kecil di perairan wilayah pengelolaan perikanan-714 Laut Banda merupakan suatu gejala penting yang perlu dicermati. Indikasi excess capacity timbul jika selisih antara kapasitas input (target) dengan input aktual dalam penangkapan bernilai negatif. Hasil estimasi kapasitas input (upaya dan unit alat penangkap ikan) perikanan pelagis kecil ditentukan oleh input aktual yang dialokasikan dan skor efisiensi relatif. Secara keseluruhan, nilai kapasitas input adalah lebih rendah, dan atau sama dengan nilai input aktual. Keragaman nilai kapasitas disebabkan fluktuasi input aktual, sehingga berpengaruh terhadap kapasitas berlebih, yang pada gilirannya berdampak terhadap penurunan ekonomi, dan inefisiensi penangkapan ikan, serta menimbulkan over fishing.

Kapasitas berlebih secara kontinu sejak tahun 1989-1999 mengindikasikan perikanan pelagis kecil di perairan wilayah pengelolaan perikanan-714 Laut Banda mengalami over capacity dalam periode tersebut. Indikasi over capacity juga diperkuat oleh fluktuasi perubahan catch per unit of effort yang cenderung menurun dalam periode tahun 1989-1999. Indikasi over capacity diakibatkan oleh peningkatan permintaan produksi ikan, sehingga nelayan atau perusahaan perikanan terdorong untuk meningkatkan produksi. Hal tersebut menyebabkan peningkatan alokasi input sehingga menimbulkan tekanan terhadap sumber daya ikan pelagis kecil. Kondisi over capacity tersebut menimbulkan kelebihan eksploitasi sumber daya ikan pelagis kecil dan penggunaan input menjadi semakin tidak efisien dalam penangkapan.

Walaupun dalam periode tahun 19852006, produksi faktual cenderung meningkat, namun upaya penangkapan cenderung menurun. Kecenderungan perubahan tersebut mengindikasikan nelayan mengurangi aktivitas penangkapan untuk meningkatkan efisiensi produksi dan manfaat ekonomi. Pengurangan aktivitas penangkapan adalah agak kontra produktif terhadap kecenderungan penambahan armada penangkapan dalam waktu yang sama. Hal ini dilakukan nelayan untuk meningkatkan produktivitasnya secara individu.

Status kapasitas penangkapan dan kebijakan penggunaan input selama periode tahun 1985-2006 diperlihatkan pada Tabel 4. Status kapasitas perikanan pelagis kecil pada periode tersebut dapat digolongkan sebagai fully utilized, excess capacity, dan over capacity, dan dikelompokan sebagai berikut, tingkat penangkapan tahun 1985 berstatus fully utilized dan diperlukan kebijakan untuk mempertahankan status tersebut; tingkat penangkapan tahun 1986 mengindikasikan excess capacity dan diperlukan kebijakan pengurangan 349 unit alat tangkap dan 55.800 trip untuk mencapai pemanfaatan kapasitas penuh; tingkat penangkapan tahun 1987 dan 1988 adalah fully utilized, dengan kebijakan mempertahankan tingkat fully utilized; tingkat penangkapan tahun 1989-1999 mengindikasikan excess capacity dalam jangka panjang atau indikasi over capacity, dan membutuhkan kebijakan pengurangan rata-rata alat tangkap 550 unit dan upaya penangkapan 85.308 trip untuk mencapai pemanfaatan kapasitas penuh; tingkat penangkapan tahun 2000 memperlihatkan kondisi fully utilized sehingga perlu dipertahankan; tingkat penangkapan tahun 2001-2004 berada pada kondisi excess capacity dan membutuhkan kebijakan pengurangan kapasitas; dan tingkat penangkapan tahun 2005 dan 2006 memperlihatkan kondisi fully utilized atau penggunaan input optimal sehingga status kapasitas perikanan pelagis kecil perlu dipertahankan. Untuk mencapai efisiensi 
perikanan, diperlukan upaya pengurangan kapasitas penangkapan melalui suatu mekanisme kontrol kapasitas perikanan seperti pengurangan modal investasi, penyesuaian alat tangkap, dan jumlahnya, penyesuaian periode maupun daerah penangkapan (Kirkley et al. , 2004; Food and Agriculture Organization, 2008).

Tabel 4. Status kapasitas dan input penangkapan pelagis kecil di wilayah pengelolaan perikanan-714 Laut Banda

Table 4. Capacity status and fishing input of small pelagic fishery at fishery management area-714 Banda Sea

\begin{tabular}{|c|c|c|c|c|c|}
\hline \multirow{2}{*}{$\begin{array}{l}\text { Periode (tahun)I } \\
\text { Period (year) }\end{array}$} & \multirow{2}{*}{$\begin{array}{c}\text { Tingkat } \\
\text { efisiensil } \\
\text { Level of } \\
\text { efficiency }\end{array}$} & \multicolumn{2}{|c|}{$\begin{array}{l}\text { Kapasitas berlebih/ } \\
\text { Excess capacity }\end{array}$} & \multirow{2}{*}{ Kondisi/Status } & \multirow{2}{*}{$\begin{array}{c}\text { Input } \\
\text { penangkapan } \\
\text { Fishing input }\end{array}$} \\
\hline & & $\begin{array}{l}\text { Upaya (trip)I } \\
\text { Effort (trip) }\end{array}$ & $\begin{array}{c}\text { API (unit)l } \\
\text { Fishing (unit) }\end{array}$ & & \\
\hline 1985 & 1,000 & 0 & 0 & Fully utilized & Dipertahankan \\
\hline 1986 & 0,909 & -55.800 & -349 & Excess capacity & Dikurangi \\
\hline 1987 & 1,000 & 0 & 0 & Fully utilized & Dipertahankan \\
\hline 1988 & 1,000 & 0 & 0 & Fully utilized & Dipertahankan \\
\hline 1989 & 0,838 & -120.124 & -651 & Over capacity & Dikurangi \\
\hline 1990 & 0,897 & -74.468 & -429 & Over capacity & Dikurangi \\
\hline 1991 & 0,931 & -56.501 & -289 & Over capacity & Dikurangi \\
\hline 1992 & 0,951 & -63.512 & -209 & Over capacity & Dikurangi \\
\hline 1993 & 0,915 & -61.508 & -369 & Over capacity & Dikurangi \\
\hline 1994 & 0,882 & -87.392 & -561 & Over capacity & Dikurangi \\
\hline 1995 & 0,925 & -65.761 & -400 & Over capacity & Dikurangi \\
\hline 1996 & 0,849 & -107.286 & -826 & Over capacity & Dikurangi \\
\hline 1997 & 0,881 & -87.869 & -616 & Over capacity & Dikurangi \\
\hline 1998 & 0,763 & -175.004 & -1.369 & Over capacity & Dikurangi \\
\hline 1999 & 0,931 & -38.966 & -334 & Over capacity & Dikurangi \\
\hline 2000 & 1,000 & 0 & -0 & Fully utilized & Dipertahankan \\
\hline 2001 & 0,869 & -59.836 & -871 & Excess capacity & Dikurangi \\
\hline 2002 & 0,903 & -34.987 & -812 & Excess capacity & Dikurangi \\
\hline 2003 & 0,890 & -36.685 & -1.098 & Excess capacity & Dikurangi \\
\hline 2004 & 0,849 & -46.027 & -1.690 & Excess capacity & Dikurangi \\
\hline 2005 & 1,000 & 0 & 0 & Fully utilized & Dipertahankan \\
\hline 2006 & 1,000 & 0 & 0 & Fully utilized & Dipertahankan \\
\hline
\end{tabular}

Secara keseluruhan, tingkat penangkapan ikan pelagis kecil dalam periode tahun 1985-2006 telah menunjukkan status excess capacity dan indikasi over capacity. Dari perspektif pengelolaan perikanan, diperlukan kebijakan pengurangan kapasitas untuk menyeimbangkan upaya penangkapan maupun alat tangkap terhadap ketersediaan sumber daya ikan pelagis kecil di wilayah pengelolaan perikanan-714 Laut Banda untuk menghasilkan efisiensi pemanfaatan sumber daya ikan pelagis kecil. Menurut Food and Agriculture Organization (2008), pada perikanan bersifat open access, seperti di wilayah pengelolaan perikanan714 Laut Banda, langkah awal untuk mengurangi kelebihan kapasitas adalah pembatasan armada yang masuk ke industri perikanan tangkap. Selain itu, diperlukan pengelolaan kapasitas melalui pembatasan izin penangkapan untuk mengurangi kapasitas terutama perikanan yang telah terindikasi over capacity. 


\section{REKOMENDASI KEBIJAKAN}

1. Status kapasitas perikanan pelagis kecil periode tahun 1985-2006 dapat digolongkan sebagai fully utilized $27,28 \%$, excess capacity $22,72 \%$, dan over capacity 50\%. Kondisi kapasitas tersebut memperlihatkan pengelolaan perikanan pelagis kecil belum optimal dan tidak efisien dalam pemanfaatan input penangkapan, karena telah terjadi kelebihan input pada status excess capacity dan over capacity. Status excess capacity dan over capacity secara temporal atau tahunan membutuhkan kebijakan pengurangan input penangkapan untuk mencapai kapasitas penuh. Di sisi lain, status fully utilized atau kapasitas penuh menghendaki kebijakan untuk mempertahankan input penangkapan.

2. Kebijakan pengurangan kapasitas pada pengelolaan perikanan dibutuhkan untuk menyeimbangkan alat tangkap maupun upaya penangkapan terhadap ketersediaan sumber daya ikan pelagis kecil di wilayah pengelolaan perikanan714 Laut Banda. Kebijakan tersebut adalah sejalan dengan rekomendasi Food and Agriculture Organization (2008) bahwa untuk mencapai efisiensi perikanan tangkap diperlukan upaya pengurangan kapasitas penangkapan ikan. Upaya pengurangan kapasitas dapat dilakukan melalui suatu mekanisme kontrol kapasitas perikanan, yaitu pengurangan modal investasi, penyesuaian jenis dan jumlah alat tangkap, dan penyesuaian periode maupun daerah penangkapan. Dalam konteks jangka panjang, indikasi excess capacity dan over capacity pada pengelolaan perikanan menghendaki suatu rencana pengelolaan perikanan berbasis kapasitas penangkapan sebagai langkah awal eksploitasi sumber daya ikan pelagis kecil di wilayah pengelolaan perikanan-714 Laut Banda secara berkelanjutan.

\section{KESIMPULAN}

1. Kapasitas perikanan pelagis kecil periode tahun 1985-2006 telah berhasil dianalisis dengan pendekatan data envelopment analysis.

2. Analisis data envelopment analysis tipe variable return to scale dengan dua faktor input dan satu output telah memberikan hasil estimasi efisiensi teknis, skala efisiensi, dan alokasi faktor input optimal.

3. Perubahan kapasitas perikanan pelagis kecil pada tahun 1985, 1987, 1988, 2000, 2005, dan 2006 bersifat fully utilized.

4. Perikanan pelagis kecil terindikasi excess capacity, dan kondisi excess capacity tertinggi ditemui pada tahun 1998.

5. Perikanan pelagis kecil dengan efisiensi terendah terjadi pada tahun 1998, sehingga memerlukan kebijakan pengurangan faktor upaya dan alat tangkap masing-masing $23,71 \%$.

6. Terdapat indikasi over capacity pada perikanan pelagis kecil periode tahun 1989-1999. Dengan demikian, kebijakan pengurangan kapasitas dibutuhkan untuk meningkatkan efisiensi pengelolaan perikanan. 


\section{DAFTAR PUSTAKA}

Charnes, A., W. Cooper, A. Lewin, \& L. Seiford (eds). 1994. Data Envelopment Analysis: Theory, Methodology, and Application. Boston. MA: Kluwer Academic Publishers.

Coelli, T. J. 1996. A Guide to DEAP Version 2.1: A Data Envelopment Analysis Program. CEPA Working Papers. Department of Econometrics University of New England. Australia. 50 pp.

Desniarti. 2007. Analisis kapasitas perikanan pelagis di perairan pesisir Provinsi Sumatera Barat. Disertasi. Sekolah Pascasarjana. Institut Pertanian Bogor. Bogor. 181 pp.

Departemen Kelautan dan Perikanan. 2006. Statistik Kelautan dan Perikanan Tahun 2005. Departemen Kelautan dan Perikanan. 314 pp.

Efendi, S. E. 2007. Analisis kapasitas berlebih perikanan pukat cincin Pekalongan dalam kerangka kebijakan perikanan tangkap di Laut Jawa dan Sekitarnya. Thesis. Sekolah Pascasarjana. Institut Pertanian Bogor. $126 \mathrm{pp}$.

Food and Agriculture Organization. 2008. Fisheries management: 3 . Managing Fishing Capacity. FAO Technical Guidelines for Responsible Fisheries. No.4 Suppl. 3. Roma. FAO. 104 pp.

Fare, R., S. Grosskopf, \& E. Kokkelenberg. 2000. Data Envelopment Analysis: A Framework for Assessing Capacity in Fisheries when Data are Limited. Presented at the International Institute of Fisheries Economics and Trade Conference. IIFET X 2000, July.
Fauzi, A. 2005. Kebijakan perikanan dan kelautan. Isu, Sintesis, dan Gagasan. PT. Gramedia Pustaka Utama. 185 pp.

Fauzi, A. \& S. Anna. 2005. Pemodelan Sumber daya Perikanan dan Kelautan untuk Analisis. PT Gramedia Pustaka Utama. Jakarta. 343 pp.

Hiariey, J. 2009. Status eksploitasi sumber daya ikan pelagis kecil di perairan Maluku dan kapasitas penangkapannya. Disertasi. Sekolah Pascasarjana. Institut Pertanian Bogor. Bogor. 259 pp.

Kirkley, J. E. \& D. Squires. 1998. Measuring capacity and capacity utilization in fisheries. Background Paper Prepared for FAO Technical Working Group on the Management of Fishing Capacity. La Jolla. USA. Forthcoming. FAO Fisheries Report. 160 pp.

Kirkley, J. E., C. J. M. Paul, \& D. Squires. 2004. Deterministic and Stochastic Capacity Estimation for Fishery Capacity Reduction. Marine Resources Economics. Marine Resources Foundation. USA. 19: 271-294.

Lindebo, E. 2004. Managing Capacity in Fisheries. Food and Resources Institute. FOI. Rolighedsvej. 258 pp.

Merta, I G. S., S. Nurhakim, \& J. Widodo. 1998. Sumber daya perikanan pelagis kecil. Dalam: Potensi dan Penyebaran Sumber Daya Ikan Laut di Perairan Indonesia. (Editor) J. Widodo, K. A. Aziz, B. E. Priyono, G. H. Tampubolon, N. Naamin, \& A. Djamali. Komisi Nasional Pengkajian Stok Sumber Daya Ikan Laut. Lembaga IImu Pengetahuan Indonesia. 89-106. 
Nurhakim, S., V. P. H. Nikijuluw, D. Nugroho, \& B. I. Prisanto. 2007. Status perikanan menurut wilayah pengelolaan. Informasi Dasar Pemanfaatan Berkelanjutan. Pusat Riset Perikanan Tangkap. Badan Riset Kelautan Perikanan. Departemen Kelautan dan Perikanan. 47 pp.

Van Hoof \& de Wide W. 2005. Capacity assessment of the dutch beam-trawler fleet using data envelopment analysis.
Marine Resources Economics. Marine Resources Foundation. USA 20 (4): 327 345.

Vestergaard, N., D. Squires, \& J. E. Kirkley. 2003. Output Based Measures: DEA and Peak-to-Peak Measures of Capacity in a Multispecies Danish Fishery. Pascoe and Gréboval (eds). Measuring Capacity in Fisheries. FAO. 169-180. 